\title{
Analisis Pola Spasial dan Faktor Pemilihan Lokasi Minimarket di Kabupaten Klaten
}

\author{
Bela Hidayah, Choirul Amin
}

Masuk: 08072021 / Diterima: 24102021 / Dipublikasi: 01122021

\begin{abstract}
The shopping behavior of most people continues to increase. Convenience and practicality can make people choose minimarkets as shopping centers. Minimarket is a supermarket between 300-500 m2 with many items sold and implements its retrieval system. The purpose of this study was to determine the spatial pattern of minimarket locations and analyze the factors that influence the location of minimarket distribution through demographic variables and minimarket service coverage in the Klaten Regency. Data collection techniques used three methods, namely field observation, secondary data observation, and documentation. The method of data analysis in this study used the nearest neighbor analysis technique (ANN) with the help of the Arc GIS 10.3 application. The results obtained from this study are that the spatial pattern of the distribution of minimarket locations in the Klaten Regency is clustered. The location selection factor is seen in terms of demographics and service coverage. This study concludes that the construction of minimarkets that are close to each other causes the distribution pattern of minimarkets to be clustered. Demographic variables and service coverage influence minimarket location selection factors. The demographic factor is that the denser the population, the more excellent the opportunity for minimarket development. The service coverage factor has not been able to serve the Klaten Regency area with a radius of 300 meters per one minimarket unit.
\end{abstract}

Key words: Minimarket; ANN; Spatial Pattern

Abstrak Perilaku belanja sebagian besar masyarakat terus meningkat. Kenyamanan dan kepraktisan mampu membuat masyarakat memilih minimarket sebagai tempat pusat perbelanjaan. Minimarket merupakan pasar swalayan dengan ukuran antara 300-500 $\mathrm{m}^{2}$ dengan jumlah item barang yang dijual cukup besar dan menerapkan system pengambilan barang sendiri. Tujuan dari penelitian ini adalah mengetahui pola spasial lokasi minimarket dan menganalisis faktor yang mempengaruhi lokasi persebaran minimarket melalui variabel demografi dan jangkauan pelayanan minimarket di Kabupaten Klaten. Teknik pengumpulan data menggunakan tiga metode yakni observasi lapangan, observasi data sekunder dan dokumentasi. Metode analisis data dalam penelitian ini digunakan teknik analisis tetangga terdekat (ANN) dengan bantuan aplikasi Arc GIS 10,3. Hasil yang diperoleh dari penelitian ini adalah pola spasial sebaran lokasi minimarket di Kabupaten Klaten adalah mengelompok. Adapun faktor pemilihan lokasi dilihat dari segi demografis dan jangkauan pelayanan. Kesimpulan dari penelitian ini adalah pembangunan minimarket yang jaraknya berdekatan satu sama lain menyebabkan pola sebaran minimarket mengelompok (clustered). Faktor pemilihan lokasi minimarket dipengaruhi oleh variabel demografi dan jangkauan pelayanan. Faktor demografi yaitu semakin padat penduduknya maka peluang pembangunan minimarket semakin besar. Faktor jangkauan pelayanan belum mampu melayani daerah Kabupaten Klaten dengan radius 300 meter per unit minimarket.

Kata kunci: Minimarket; $A N N$; Pola Spasial

This is an open access article under the CC BY-SA license.

Copyright @ 2021 by Author. Published by Universitas Pendidikan Ganesha.

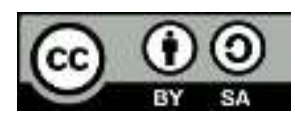




\section{Pendahuluan}

Kebutuhan manusia semakin hari akan terus meningkat, sehingga tempat perbelanjaan masyarakat juga harus terus tercukupi. Seperti minimarket dimana saat ini disetiap wilayah pasti terdapat minimarket sebagai tempat belanja untuk memenuh kebutuhan hidup sehari-hari manusia. Menurut Perda Nomor 2 Tahun 2008 tentang penataan dan pembinaan pasar tradisional di Kabupaten Klaten menjelaskan bahwa minimarket adalah sarana atau tempat usaha untuk melakukan penjualan barang-barang kebutuhan sehari-hari secara eceran langsung kepada konsumen dengan cara pelayanan mandiri.

Minimarket merupakan toko yang mengisi kebutuhan akan warung yang lebih modern dan dekat dengan area permukiman penduduk, sehingga dapat mengungguli toko dan warung tradisional. Minimarket adalah pasar swalayan dengan ukuran antara 300 $500 \mathrm{~m}^{2}$ dengan jumlah item barang yang dijual cukup besar dan menerapkan system pengambilan barang sendiri. Adanya persebaran lokasi minimarket menghasilkan pola persebaran tersendiri menurut kebutuhan manusia, (Astri, 2009). Pola sebaran merupakan model suatu objek (minimarket) suatu daerah yang tampak di permukaan bumi.

Minimarket termasuk dalam kategori pasar modern dimana menjual eceran bahan konsumsi yang berupa makanan dan produk rumah tangga

${ }^{1}$ Bela Hidayah, ${ }^{1}$ Choirul Amin

${ }^{1}$ Universitas Muhammadiyah Surakarta, Indonesia

belaahidayah@gmail.com untuk melayani manusia yang berada di sekitarnya daam mememnuhi kebutuhan hidup, (Widyarti and Fardani, 2020). Demand and Suply konsumen di suatu pasar dipengaruhi oleh pertumbuhan ekonomi, (Wibowo, Rengkung, and Mastutie 2015). Perilaku konsumen merupakan proses seseorang untuk melakukan pembelian atau tidak (Hariyadi, 2016).

Persebaran minimarket terus berkembang di setiap wilayah, salah satunya yakni minimarket di Kabupaten Klaten. Kabupaten Klaten merupakan salah satu provinsi di Jawa Tengah. Menurut (Sambiran, 2020), adanya perizinan minimarket menyebabkan usaha-usaha kecil di sekitarnya mengalami penurunan omset dikarenakan sepinya pembeli. Berdasarkan SNI Nomor 3 Tahun 2004, disebutkan bahwa satu minimarket dapat melayani 250 jiwa dengan radius pencapaian 300 meter, (Saskara, 2020). Swalayan merupakan toko yang menyediakan segala kebutuhan seharihari. Swalayan menggunakan konsep ritel modern yaitu berupa pelayanan mandiri dan menjual berbagai jenis barang ecara eceran (Rahayu, 2018).

Pola spasial merupakan hasil bentuk fisik atau sosial pada suatu wilayah di permukaan bumi. Pola spasial menjadi topik yang sangat penting di berbagai aspek seperti pada ekologi tropis karena perbedaan yang tinggi di daerah tropis memunculkan kepadatan yang rendah (Condit, 2000)

Pola Persebaran dipengaruhi oleh beberapa faktor terutama faktor ekonomi dan demografi. Adanya perubahan perilaku konsumen dipengaruhi oleh beberapa pembaharuan pemasaran dan strategi 
bauran pemasaran (Syaharudin, 2013). Letak geografis sangat penting untuk di berbagai kalangan tempat. Lokasi geografis juga berperan penting dalam pelayanan public karena menentukan etersediaan barang dan jasa di tingkat lokal (Cabras, 2011). Adanya fasilitas minimarket juga menimbulkan dampak negatif bagi masyarakat dan dapat memicu konflik yakni mematikan pasar tradisional. Persaingan antara minimarket dan pasar tradisional disebabkan karena fasilitas serta kenyamanan yang tersedia di kedua tempat tersebut, (Ilmawan, 2015). Selain itu, program pemasaran juga mempengaruhi konsumen menyadari kebutuhannya (Maming, 2017). Desain spasial yang dilihat di peta ditentukan oleh representasi spasial, karakter spasial, komponen pengumpulan informasi, komponen spasial, dan komponen yang mencakupinya (Long \& Robertson, 2017).

Wujud dari upaya dalam sarana untuk tempat jual beli kebutuhan masyarakat adalah adanya minimarket yang telah tersedia di sepanjang jalan dari kota ke kota dan di daerah ke daerah (Zarkassi and Ispriyarso, 2019). Bagian dari perdagangan eceran dalam saluran promosi bagi produsen meliputi barang, pembiayaan, promosi dan promosi, pembeli, dan pesaing. Berkaitan dengan barang tersebut adalah meliputi transportasi, kapasitas, pendirian, perbaikan, pengumpulan, dan penentuan keberadaan. Dalam subsidi, yang diberikan kepada pembeli, mengurangi beban pembuat. Promosi dan kemajuan oleh bisnis ritel meningkatkan kapasitas iklan. Produsen juga mendapatkan data tentang pembeli dan pesaing dari pengecer, sehingga mereka dapat menilai barang yang mereka miliki dan kualitas pesaing (Utomo, 2009).

Dimanika

kependudukan

manusia meliputi ukuran, struktur dan distribusi penduduk serta perubahan jumlah penduduk akibat kelahiran, kematian, migrasi dan penuaan (Natoen 2018). Faktor demografi yaitu struktur umur, struktur perkawinan, umur kawin pertama, paritas, disrupsi perkawinan dan proporsi yang kawin. Faktor non demografi yaitu ekonomi, pendidikan, urbanisasi, industrialisasi dan perbaikan status perempuan. Kehadiran ritel maju di sekitar pasar konvensional akan berdampak pada penurunan jumlah pembeli yang berbelanja di pasar konvensional, karena akan terjadi perpecahan (Sarwoko, 2008).

Jangkauan pelayanan berkaitan dengan jarak serta Kepuasan Pelanggan sangatlah penting. Menurut (Rizqiawan and Prihantono 2020), Kepuasan Pelanggan adalah konsekuensi dari perbandingan yang dilakukan oleh pelanggan yang membandingkan antara tingkatan dari manfaat yang dirasakan terhadap apa yang di harapkan pelanggan. Menurut (Priyanka \& Yuliani 2017). Berkembangnya kegiatan perdagangan dapat memicu jumlah peningkatan sarana di suatu wilayah tersebut. Dari permasalahan tersebut, maka dari itu penelitian ini perlu dilakukan yang bertujuan untuk mengetahui pola spasial lokasi minimarket dan menganalisis faktor yang mempengaruhi lokasi persebaran minimarket melalui variabel demografi dan jangkauan pelayanan minimarket di Kabupaten Klaten. 


\section{Metode}

Metode penelitian yang digunakan dalam penelitian ini adalah metode pendekatan kuantitatif. Teknik pengumpulan data menggunakan dua metode yaitu observasi dan dokumentasi. Metode pengumpulan data observasi dilakukan dengan pengambilan titik koordinat minimarket dengan bantuan aplikasi Global Positioning System (GPS), serta dengan observasi data sekunder melalui titik koordinat di Google Maps. Metode pengumpulan data melalui teknik dokumentasi yaitu pengambilan gambar minimarket secara langsung dengan format JPG foto digital. Metode analisisdata dalam penelitian ini digunakan teknik analisis tetangga terdekat Average Nearest Neighbour Analysis (ANN). Tenik ini bertujuan untuk menentukan pola sebaran lokasi minimarket dengan cara otomatis yakni dengan bantuan software aplikasi Arc GIS 10.3. Teknik dalam mengetahui faktor-faktor yang mempengaruhi terhadap lokasi minimarket digunakan teknik analisis spasial ekonometri yaitu dengan pertimbangan demografi dan jangkauan layanan minimarket, dengan rumus sebagai berikut.

Persebaran Berdasarkan Demografi = Jumlah Penduduk Kecamatan

$\overline{\text { Jumlah Penduduk Yang Dilayani (250) }}$

Jangkauan Layanan Minimarket = Luas Kecamatan $\left(\mathrm{m}^{2}\right)$

Luas Radius Pelayanan $\left(\mathrm{m}^{2}\right)$

\section{Hasil dan Pembahasan}

\section{Pola Spasial Sebaran Lokasi Minimarket}

Minimarket merupakan tempat perbelanjaan yang menjual segalakebutuhan sehari-hari manusia dengan pelayanan mandiri yaitu pengambilan barang sendiri. Sebagian besar manusia sekarang memilih berbelanja kebutuhan sehari-hari di minimarket. Kenyamanan dan kepraktisan membuat manusia betah berbelanja di minimarket. Serta semua kebutuhan sehari-hari juga tersedia disana, mulai dari berbagai macam makanan, perlengkapan mandi, perlengkapan masak sampai perlengkapan make up juga tersedia disana.

Hasil cek lapangan dengan pertimbangan observasi data sekunder dihasilkan data bahwa di Kabupaten Klaten terdapat 609 minimarket yang terdiri dari 48 indomaret, 83 alfamart, 4 minimarket jaringan, 1 coco market, 1 java market dan sisanya adalah minimarket perseorangan yang termasuk non-jaringan ditunjukkan pada Tabel 1. Minimarket yang merupakan usaha jaringan tersebar dengan jumlah 131unit sedangkan untuk minimarket non-jaringan tersebar sebanyak 474 unit yang tersebar di wilayah Kabupaten Klaten.

Tabel 1. Sebaran Lokasi Minimarket

\begin{tabular}{llll}
\hline No. & Nama Minimarket & Klasifikasi Usaha & Jumlah \\
\hline 1. & Indomaret & Jaringan & 48 \\
2. & Alfamart & Jaringan & 83 \\
3. & Minimarket & Jaringan & 4 \\
4. & Assalamm Mart & Non-Jaringan & 1 \\
5. & Coco Market & Non-Jaringan & 1 \\
6. & Java Market & Non-Jaringan & 1 \\
7. & Minimarket Perseorangan & Non-Jaringan & 471 \\
\hline & Jumlah & & 609 \\
\hline
\end{tabular}


Analisis Pola Spasial Dan Faktor Pemilihan Lokasi Minimarket di Kabupaten Klaten/Bela Hidayah, Choirul Amin

Minimarket tersedia di masingmasing kecamatan dengan jumlah yang berbeda sesuai kebutuhan dan perizinan. Pembangunan minimarket berada di lokasi yang strategis yang dekat dengan permukiman. Tidak hanya di jalan utama atau jalan raya saja tapi bahkan dibangun di beberapa jalan kecil seperti jalan lokal dan jalan gang kecil yang sempit. Pembangunan minimarket yang terpenting adalah dekat dengan daerah permukiman. Karena konsumen memilih tempat belanja yang jaraknya tidak terlalu jauh dengan rumah mereka.

Berdasarkan hasil tersebut diketahui bahwa minimarket yang paling dominan berada di Kecamatan Klaten Tengah. Oleh karena itu banyak kegiatan ekonomi yang dilakukan penduduk Klaten salah satunya adalah berdagang. Minimarket jaringan dan non-jaringan merupakan dua hal yang berbeda.

Minimarket dengan usaha jaringan merupakan jenis minimarket yang dikelola oleh perusahaan dan dalam pelaksanaannya diperlukan tenaga kerja. Berbeda dengan minimarket non-jaringan, yang dikelola langsung secara perseorangan, seperti halnya toko kelontong. Oleh karena itu hasil pendapatan minimarket langsung dipegang sendiri oleh pemiliknya. Minimarket non-jaringan sebagian besar adalah milik perseorangan sehingga mereka membangun minimarket di sekitar rumah mereka sendiri atau bahkan di tempat tinggal mereka sendiri dan memudahkan konsumen untuk datang untuk berbelanja tidak perlu memakan waktu yang lama karena lokasi minimarket dekat dengan rumah mereka.

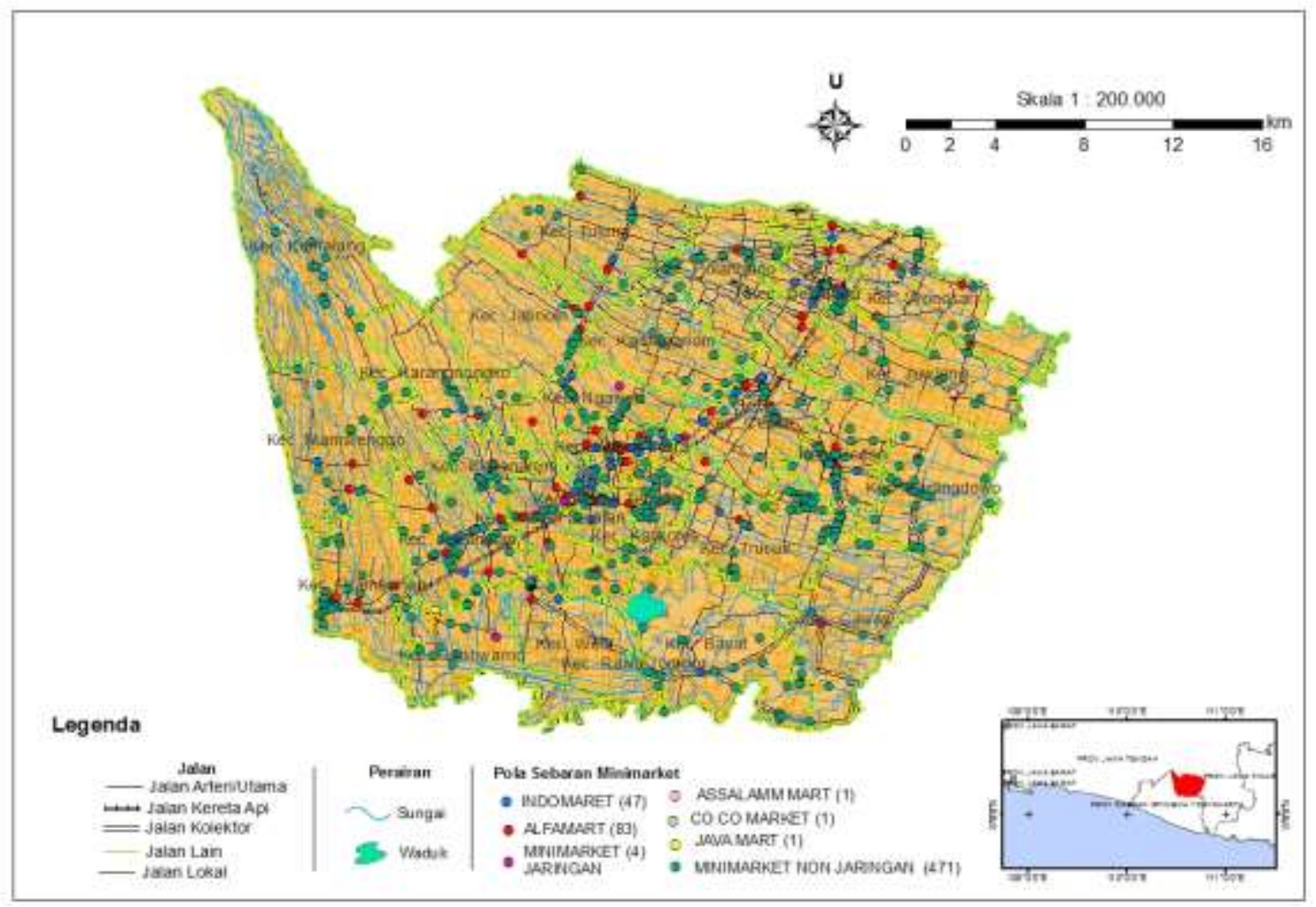

Gambar 2. Peta Sebaran Lokasi Minimarket Kabupaten Klaten 
Berdasarkan hasil analisis tetangga terdekat (ANN) menunjukkan bahwa pola sebaran lokasi minimarket di Kabupaten Klaten adalah mengelompok (clustered). Hal tersebut dikarenakan hasil ANN menunjukkan nilai critical value (Z-Score) $<-2,58$ dengan nilai Nearest Neighbor Ratio 0,677565 dimana jarak rata - rata antar minimarket 302 meter ditunjukkan pada Gambar 3. Hal ini sama seperti temuan penelitian sebelumnya yang dilakukan (Saskara, 2020) terhadap persebaran lokasi minmarket di Kota Denpasar menunjukkan bahwa dengan metode sama hasil analisis adalah termasuk dalam lasifikasi mengelompok dengan nilai Nearest Neighbor Ratio sebesar 0,611404 dan jarak rata - rata minmarket 145 meter. Jarak antar minimarket di Kabupaten Klaten lebih jauh dibandingkan dengan jarak antar minmarket di Kota Denpasar.

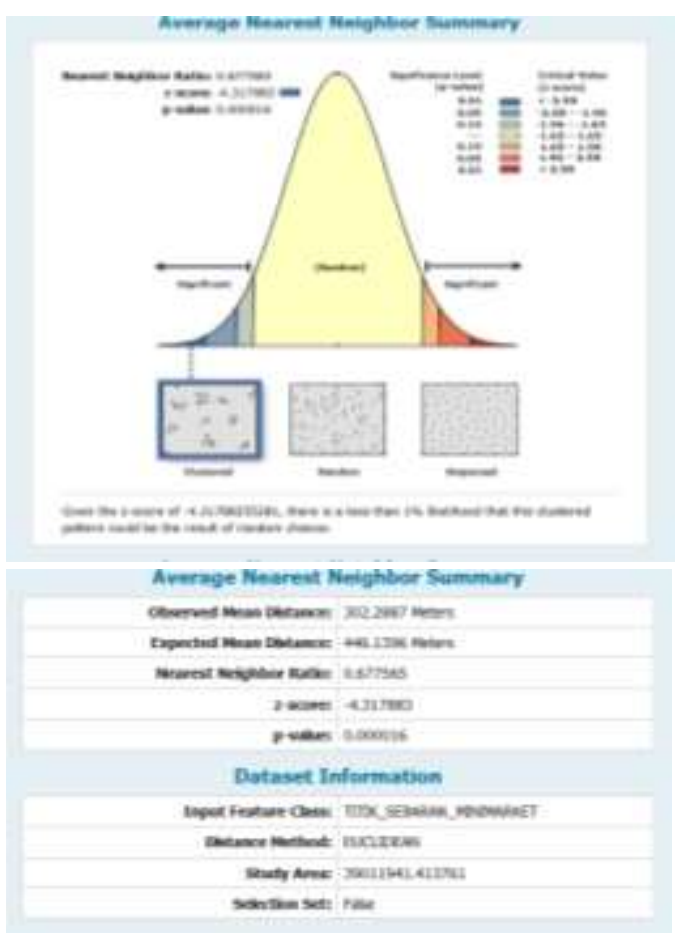

Gambar 3. Hasil Analisis Pola Sebaran Minimarket di Kabupaten Klaten

\section{Analisis Sebaran Lokasi Minimarket Berdasarkan Demografi di Kabupaten Klaten}

Menurut (Dhamardiatmika, 2016) pola sebaran spasial merupakan pola persebaran dengan batas ruang atau distribusi apsial tata guna lahan di dalam suatu wilayah. Selain daripada metode ANN yang dijelaskan diatas. Secara tidak langsung pola sebaran minimarket dapat ditentukan dari segi aspek kependudukan yaitu demografi. Hal tersebut dikarenakan sebaran minimarket adalah salah satu sarana dan prasarana yang dibangun oleh pemerintah daerah yang berdasarkan kebutuhan dari masyarakat setempat untuk mencukupi kebutuhan pokok sehari - hari mereka. Kajian demografi meliputi ukuran, struktur dan distibusi penduduk. Sehingga hubungan antara persebaran lokasi minimarket dengan demografi adalah jumlah penduduk yang menjadi konsumen disekitar lokasi minimarket dengan jarak tertentu.

Pola sebaran minimarket di Kabupaten Klaten dipengaruhi oleh adanya faktor demografi yaitu jumlah penduduk di setiap wilayahnya sehingga menampilkan bentuk dari pola sebaran tersebut. Hasil analisis pola sebaran minimarket berdasarkan demografi ditunjukkan pada Gambar 4. Berdasarkan hasil tersebut menunjukkan bahwa lokasi minimarket berpusat di Kecamatan Tengah dan Kecamatan Utara yang mana kecamatan tersebut merupakan pusat Kabupaten Klaten. Hal ini dipengaruhi oleh jumlah penduduk yang tinggi. Bedasarkan hasil analisis kepadatan penduduk, kecamatan yang padat penduduknya adalah berada di Kecamatan Tengah dan Kecamatan 
Analisis Pola Spasial Dan Faktor Pemilihan Lokasi Minimarket di Kabupaten Klaten/Bela Hidayah, Choirul Amin

Utara. Maka dari itu, semakin padat penduduknya, maka semakin banyak lokasi minimarket yang tersedia. Adanya minimarket menjadikan pesaing bagi pasar tradisional karena minimarket mampu menarik masyarakat untuk berbelanja, hal tersebut dikarenakan kehadiran minimarket yang lebih nyaman, bersih dan kelengkapan jenis barang dibandingkan dengan pasar tradisional. Selain itu dapat memunculkan iklim persaingan yang tidak sehat yaitu dapat merugikan pasar tradisional.

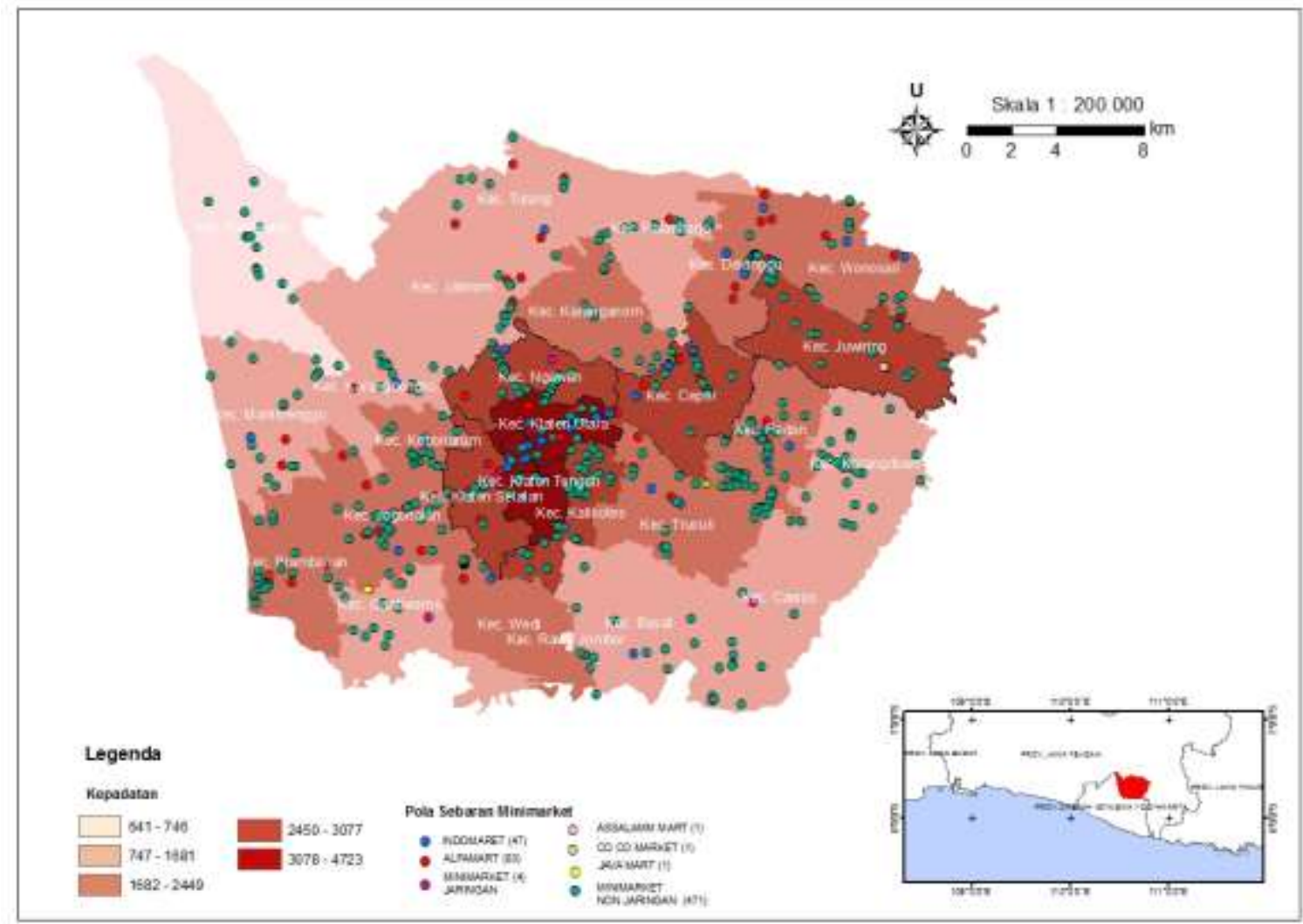

Gambar 4. Peta Analisis Kepadatan Penduduk Kabupaten Klaten

Selain analisis menggunakan ArcGIS, menentukan faktor demografi juga dapat dilakukan dengan mengunakan perhitungan yang ditunjukkan pada Tabel 2. Konsumen merupakan komponen penting dalam proses jual beli. Konsumen adalah penduduk yang bersedia membeli barang keperluan di minmarket. Oleh karena itu komponen yang diperlukan dalam perhitungan adalah jumlah penduduk serta jumlah penduduk yang dapat dilayani sesuai peraturan perizinan pemerintah. Jumlah penduduk yang dilayani merupakan jumlah penduduk yang dapat memuat untuk berbelanja di tiap 1 unit meter minimarket. Berdasarkan BPS Kabupaten Klaten, jumlah penduduk di Kabupaten Klaten adalah 1.260.506 jiwa, Dan jumlah penduduk yang dapat berbelanja adalah 250 orang dalam 1 unit meter minimarket. 
Analisis Pola Spasial Dan Faktor Pemilihan Lokasi Minimarket di Kabupaten Klaten/Bela Hidayah, Choirul Amin

Tabel 2. Hasil Perhitungan Sebaran Minimarket Berdasarkan Demografi

\begin{tabular}{|c|c|c|c|c|c|}
\hline No. & Kecamatan & $\begin{array}{c}\text { Jumlah } \\
\text { Penduduk }\end{array}$ & $\begin{array}{c}\text { Jumlah } \\
\text { Penduduk Yang } \\
\text { Dilayani (Per } 1 \\
\text { Unit Meter) }\end{array}$ & Rumus & Unit \\
\hline 1 & Prambanan & 52.592 & 250 & $\frac{52.592}{250}=210,368$ & 210 \\
\hline 2 & Gatiwarno & 38.144 & 250 & $\frac{38.144}{250}=152,576$ & 153 \\
\hline 3 & Wedi & 51.442 & 250 & $\frac{51.442}{250}=205,768$ & 206 \\
\hline 4 & Bayat & 61.191 & 250 & $\frac{61.191}{250}=244,764$ & 245 \\
\hline 5 & Cawas & 56.101 & 250 & $\frac{56.101}{250}=224,404$ & 224 \\
\hline 6 & Trucuk & 77.206 & 250 & $\frac{77.206}{250}=308,824$ & 309 \\
\hline 7 & Kalikotes & 37.051 & 250 & $\frac{37.051}{250}=148,204$ & 148 \\
\hline 8 & Kebonarum & 19.289 & 250 & $\frac{19.289}{250}=77,156$ & 77 \\
\hline 9 & Jogonalan & 59.628 & 250 & $\frac{59.628}{250}=238,512$ & 239 \\
\hline 10 & Manisrenggo & 43.242 & 250 & $\frac{43.242}{250}=172,968$ & 173 \\
\hline 11 & Karangnongko & 36.304 & 250 & $\frac{36.304}{250}=145,216$ & 145 \\
\hline 12 & Ngawen & 45.235 & 250 & $\frac{45.235}{250}=180,94$ & 181 \\
\hline 13 & Ceper & 64.305 & 250 & $\frac{64.305}{250}=257,22$ & 257 \\
\hline 14 & Pedan & 46.942 & 250 & $\frac{46.942}{250}=187,768$ & 188 \\
\hline 15 & Karangdowo & 42.515 & 250 & $\frac{42.515}{250}=170,06$ & 170 \\
\hline 16 & Juwiring & 57.764 & 250 & $\frac{57.764}{250}=231.056$ & 231 \\
\hline 17 & Wonosari & 62.115 & 250 & $\frac{62.115}{250}=248,46$ & 248 \\
\hline 18 & Delanggu & 41.041 & 250 & $\frac{41.041}{250}=164,164$ & 164 \\
\hline 19 & Polanharjo & 40.065 & 250 & $\frac{40.065}{250}=160,26$ & 160 \\
\hline 20 & Karanganom & 45.219 & 250 & $\frac{45.219}{250}=180,876$ & 181 \\
\hline 21 & Tulung & 51.850 & 250 & $\frac{51.850}{250}=207,4$ & 207 \\
\hline 22 & Jatinom & 58.953 & 250 & $\frac{58.953}{250}=235.812$ & 236 \\
\hline 23 & Kemalang & 38.547 & 250 & $\frac{38.547}{250}=154.188$ & 154 \\
\hline 24 & Klaten Selatan & 44.316 & 250 & $\frac{44.316}{250}=177,264$ & 177 \\
\hline 25 & Klaten Tengah & 40.421 & 250 & $\frac{40.421}{250}=161.684$ & 162 \\
\hline \multirow[t]{2}{*}{26} & Klaten Utara & 49.028 & 250 & $\frac{49.028}{250}=196.112$ & 196 \\
\hline & Jumlah & 1260506 & & 42 & 50 \\
\hline
\end{tabular}

Sumber: Analisis Data Primer (2021)

Berdasarkan hasil perhitungan dengan rumus persebaran berdasarkan demografi menunjukkan terdapat 5.042 unit minimarket dengan jumlah penduduk yang dilayani 250 per 1 unit meter. Dan total penduduk Kabupaten 
Klaten adalah 1,2 juta jiwa penduduk. Hal ini menunjukkan hasil observasi lapangan dan observasi data sekunder tidak sinkron dengan hasil perhitungan jumlah minimarket berdasarkan demografi.

Minimarket hasil observasi lapangan dan obeservasi data sekunder berjumlah 609 unit sedangkan jumlah minimarket berdasarkan perhitungan demografi adalah melebihi 609 unit. Oleh karena itu perlu adanya penambahan pembangunan minimarket sebanyak 4.433 unit.

Seperti yang ditunjukan pada Kecamatan Trucuk, berdasarkan observasi minimarket berjumlah 42 unit sedangkan menurut hasil perhitungan berdasarkan demografi dengan jumlah penduduk yang dilayani 250 per 1 unit meter yang dihitung secara manual, minimarket harus berjumlah 327 unit. Sehingga menunjukkan bahwa minimarket di Kabupaten Klaten berdasarkan jumlah penduduk belum memenuhi syarat terpenuhinya kebutuhan minimarket sebagai tempat perbelanjaan manusia.

\section{Analisis Jangkauan Pelayanan Minimarket}

Pendirian lokasi minimarket berdasarkan pada Rencana Tata Ruang Wilayah Kabupaten/ Kota dan Rencana Detail Tata Ruang Kabupaten/ Kota adalah tidak diberlakukannya pendirian di jaringan jalan dengan system pelayanan local dan lingkungan (Setyawan, 2009). Seorang konsumen pasti memilih untuk berbelanja yang dekat dengan rumahnya sehingga tidak memerlukan banyak waktu. Jarak yang harus dijangkau ke tempat perbelanjaan lebih dekat. Hasil perhitungan analisis jangkauan pelayanan minimarket di Kabupaten Klaten ditunjukkan pada Tabel 3. Hasil perhitungan analisis jangkauan pelayanan minimarket menunjukkan penyebaran dengan 2.320 unit. Dimana untuk Kecamatan Prambanan 86 unit dengan luas wilayah 24,42 $\mathrm{km}^{2}$, Kecamatan Wonosari 110 unit dengan luas wilayah $31,14 \mathrm{~km}^{2}$ dan Kecamatan Klaten Utara 37 unit dengan luas wilayah $10,38 \mathrm{~km}^{2}$. Oleh karena itu hal tersebut dipengaruhi oleh luas wilayah. Semakin luas wilayahnya maka semakin banyak unit minimarket yang diperlukan.

Tabel 3. Hasil Perhitungan Minimarket Berdasarkan Jangkauan Pelayanan

\begin{tabular}{|c|c|c|c|c|c|}
\hline No & $\begin{array}{l}\text { Desa/ } \\
\text { Kelurahan }\end{array}$ & $\begin{array}{l}\text { Luas } \\
\left(\mathrm{km}^{2}\right)\end{array}$ & $\begin{array}{l}\text { Radius } \\
\text { Pelayanan } \\
\text { Per } 1 \text { Unit } \\
\text { (m) }\end{array}$ & $\begin{array}{l}\text { Luas } \\
\text { Radius } \\
\text { Pelayanan } \\
\left(\mathrm{m}^{2}\right)\end{array}$ & Rumus $\left(\mathrm{m}^{2}\right)$ \\
\hline
\end{tabular}

\begin{tabular}{lllllll}
\hline 1 & Prambanan & 24,42 & 300 & 282.600 & $\frac{24420000}{282.600}=86,41$ & 86 \\
2 & Gatiwarno & 25,64 & 300 & 282.600 & $\frac{25640000}{282.600}=90,73$ & 91 \\
3 & Wedi & 24,38 & 300 & 282.600 & $\frac{24380000}{282.600}=86,27$ & 86 \\
4 & Bayat & 39,43 & 300 & 282.600 & $\frac{39430000}{282.600}=139,53$ & 140 \\
5 & Cawas & 34,47 & 300 & 282.600 & $\frac{34470000}{282.600}=121,97$ & 122
\end{tabular}


Analisis Pola Spasial Dan Faktor Pemilihan Lokasi Minimarket di Kabupaten Klaten/Bela Hidayah, Choirul Amin

\begin{tabular}{lllllll}
6 & Trucuk & 33,81 & 300 & 282.600 & $\frac{33810000}{282.600}=119,64$ & 120 \\
7 & Kalikotes & 12,98 & 300 & 282.600 & $\frac{12980000}{282.600}=45,93$ & 46 \\
8 & Kebonarum & 96,70 & 300 & 282.600 & $\frac{9670000}{28.200}=34,22$ & 34 \\
9 & Jogonalan & 26,70 & 300 & 282.600 & $\frac{2670000}{282.600}=94,48$ & 94 \\
10 & Manisrenggo & 26,96 & 300 & 282.600 & $\frac{26960000}{282.600}=95,40$ & 95 \\
11 & Karangnongko & 26,74 & 300 & 282.600 & $\frac{26740000}{282.600}=94,62$ & 95 \\
12 & Ngawen & 16,99 & 300 & 282.600 & $\frac{16990000}{282.600}=60,12$ & 60 \\
13 & Ceper & 24,44 & 300 & 282.600 & $\frac{24440000}{282.600}=86,48$ & 86 \\
14 & Pedan & 19,17 & 300 & 282.600 & $\frac{19170000}{282.600}=67,83$ & 68 \\
15 & Karangdowo & 29,23 & 300 & 282.600 & $\frac{29230000}{282.600}=103,43$ & 103 \\
16 & Juwiring & 29,79 & 300 & 282.600 & $\frac{29700000}{282.600}=105,41$ & 105 \\
17 & Wonosari & 31,14 & 300 & 282.600 & $\frac{31140000}{282.600}=110,19$ & 110 \\
18 & Delanggu & 18,77 & 300 & 282.600 & $\frac{18770000}{282.600}=66,42$ & 66 \\
19 & Polanharjo & 23,84 & 300 & 282.600 & $\frac{23840000}{282.600}=84,36$ & 84 \\
20 & Karanganom & 24,06 & 300 & 282.600 & $\frac{24060000}{282.600}=85,14$ & 85 \\
21 & Tulung & 32,00 & 300 & 282.600 & $\frac{32000000}{282.600}=113,23$ & 113 \\
22 & Jatinom & 35,53 & 300 & 282.600 & $\frac{35530000}{282.600}=125,73$ & 126 \\
23 & Kemalang & 51,66 & 300 & 282.600 & $\frac{51660000}{282.600}=182,80$ & 183 \\
24 & Klaten Selatan & 14,43 & 300 & 282.600 & $\frac{14430000}{282.600}=51,06$ & 51 \\
25 & Klaten Tengah & 89,20 & 300 & 282.600 & $\frac{8920000}{282.600}=31,56$ & 32 \\
26 & Klaten Utara & 10,38 & 300 & 282.600 & $\frac{18380000}{282.600}=36,73$ & 37 \\
\hline & Jumlah & 655,56 & & & & 2.320 \\
\hline Sum & Der Analsis Data & & & & \\
\hline
\end{tabular}

Sumber: Analisis Data Primer (2021)

\section{Berdasarkan ketentuan} penjualan yang berlaku bahwa dengan jarak radius pencapaian 300 meter dimana satu minimarket dapat melayani 250 pelanggan menunjukkan hasil yaitu terdapat minimarket yang saling berdekatan antara satu minimarket dengan minimarket lainnya sehingga menyebabkan penumpukan konsumen atau pengantrian konsumen pada satu titk minimarket. Kecamatan yang sudah memenuhi syarat dengan adanya pelayanan jangkauan minimarket adalah Kecamatan Kalikotes, Kebonarum, Klaten Selatan, Klaten Tengah dan Kecamatan Klaten Utara. Kelima kecamatan tersebut memiliki system pelayanan jangkuan minimarket yang dapat ditempuh penduduk dengan jarak rumah dan lokasi minimarket yang dekat. Sehingga penduduk dapat berbelanja tanpa menghiraukan jarak, dengan kata lain lokasi minimarket dekat dengan rumah. Sedangkan untuk kecamatan lain perlu adanya penambahan minimarket yang lebih dekat dengan permukiman. Maka dari itu, jika dilihat dengan luas, sebagian besar minimarket di Kabupaten Klaten memiliki jangkauan yang relatif jauh dengan rumah dikarenakan penyebaran lokasi minimarket yang tidak merata. 


\section{Penutup}

Hasil penelitian pola spasial sebaran lokasi minimarket di Kabupaten Klaten termasuk dalam klasifikasi mengelompok (clustered) yang dipengaruhi oleh pembangunan minimarket yang jaraknya berdekatan satu sama lain. Hal tersebut dapat menyebabkan penumpukan konsumen di lokasi minimarket tertentu. Faktor pemilihan lokasi minimarket dipengaruhi oleh variabel demografi dan jangkauan pelayanan. Faktor demografi yaitu semakin padat penduduknya maka peluang pembangunan minimarket semakin besar. Faktor jangkauan pelayanan belum mampu melayani daerah Kabupaten Klaten dengan radius 300 meter per 1 unit minimarket.

\section{Daftar Pustaka}

Astri, A., et al. (2009). Pola Distribusi Spasial Minimarket Di Kota-Kota Kecil. Jurnal Perencanaan Wilayah dan Kota 20(2): 78-94.

Cabras, I. (2011). Mapping The Spatial Pattern Of Public Procurement: A Case Study From A Peripheral Local Authority In Northern England. International Journal of Public Sector Management 24(3): 187-205.

Condit, R. (2000). Spatial Patterns in the Distribution of Tropical Tree Species. Science 288(5470): 1414-18.

Dhamardiatmika, I M. A. (2016). Faktor - Faktor Pemilihan Lokasi Dan Sebaran Minimarket Waralaba Di Kecamatan Denpasar Barat. Jurnal Lingkungan Binaan 3(3): 292-304.

Hariyadi, G. T. (2016). Faktor-Faktor Yang Mempengaruhi ( Studi Pada Indomaret Dan Alfamart Di Semarang ). JPEB 1(1): 16-32.
Ilmawan, K. F. (2015). Analisis Spasial Pengaruh Keberadaan Minimarket Waralaba Terhadap Omzet Toko Kelontong Di Kecamatan Umbulharjo Kota Yogyakarta. Skripsi. Universitas Muhammadiyah Surakarta.

Long, J., \& Robertson, C. (2017). Comparing Spatial Patterns. Geography Compas 12(2): 1-33.

Maming, A. (2017). Perilaku Konsumen Dalam Keputusan Pembelian (Studi Pada Minimarket Di Kelurahan Tlogomas Kota Malang).

Natoen, A., et al. (2018). Faktor Faktor Demografi Yang Berdampak Terhadap Kepatuhan WP Badan (UMKM) Di Kota Palembang. JRTA 2(2): 101-4.

Priyanka, M. D., \& Yuliani, E. (2017). Analisis Tingkat Jangkauan Pelayanan Pengembangan Minimarket Di Koridor Jalan Terhadap Perilaku Konsumen. Jurnal Planologi 14(1): 75-88.

Rahayu, E. (2018). Pengaruh Lokasi, Kelengkapan Produk, Dan Pelayanan Terhadap Keputusan Pembelian Konsumen Pada Imam Market Kisaran. Journal of Science and Social Research 1(February): 7-12.

http://jurnal.goretanpena.com/inde x.php/JSSR/article/download/108/ 69.

Rizqiawan, H., \& Prihantono, D. (2020). Analisis Kualitas Layanan Terhadap Kepuasan Pelanggan: Perbandingan Pada Modern Retail Minimarket Dengan Toko Kelontong Di Kota Surabaya. Jurnal Manejerial Bisnis 3(3): 110.

Sambiran, S. (2020). Dampak Kebijakan Perizinan Minimarket Terhadap Usaha Kecil Di Kecamatan Kawangkoan Dan Kawangkoan Barat. Jurnal Jurusan IImu Pemerintahan 2(5): 
$1-10$.

Sarwoko, E. (2008). Dampak Keberadaan Pasar Modern Terhadap Kinerja Pedagang Pasar Tradisional Di Wilayah Kabupaten Malang. Jurnal Ekonomi Modernisasi 4(2): 97-115. https://ejournal.unikama.ac.id/inde x.php/JEKO/article/view/880/pdf_1 https://ejournal.stiepena.ac.id/inde x.php/fe/article/view/50/47.

Saskara, P. A., et al. (2020). Pola Sebaran Lokasi Minimarket Dan Faktor- Faktor Yang Mempengaruhinya Di Kota Denpasar. Jurnal Riset Planologi 1(1): 1-13.

Setyawan, A. (2009). Yang Mempengaruhi Pemilihan Lokasi Retail Modern (Studi Kasus Kota Surakarta). Skripsi. Universitas Diponegoro.

Syaharudin, M. (2013). Keberadaan Minimarket Dan Dampaknya Terhadap Ritel Tradisional Di Wilayah Perkotaan Kabupaten Jember. ISEL 3(2): 1-17.

Utomo, T. J. (2009). The Function and the Role of Retail Business in Marketing Line. Fokus Ekonomi 4(1): 44-55. https://ejournal.stiepena.ac.id/inde x.php/fe/article/view/50/47.

Wibowo, T. A., Michael, M. R., \& Mastutie, F. (2015). Pengaruh Keberadaan Minimarket Terhadap 'Warong' Di Kecamatan Malalayang. Junal Spasial: Perencanaan Wilayah dan Kota 2(2): 114-21.

Widyarti, V. S., \& Fardani, I. (2020). Studi Cakupan Wilayah Pelayanan Minimarket Dan Warung Tradisional Studi Kasus Kecamatan Bandung Kidul, Kota Bandung. Prosiding, Seminar Nasional Geomatika.
Zarkassi, H. L., \& Ispriyarso, B. (2019). Pandecta Pengawasan Dinas Perdagangan Kota Semarang Terhadap Minimarket Modern Untuk Melindungi Toko Kelontong. Jurnal penelitian IImu Hukum 13(2): 107-18. 